\title{
A handbook on
}

Legal Languages and the quest for linguistic equality in South Africa and beyond

Zakeera Docrat Russell H Kaschula Monwabisi K Ralarala

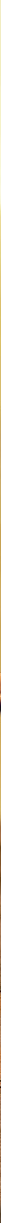




\section{INSIGHTS FROM INTERNATIONAL CASE STUDIES ON LANGUAGE AND LAW \\ Australia, Belgium, Canada and India}

This chapter mirrors Chapter 2 in a sense in that we present comparative case studies of language and law in four countries, though these are beyond the African continent. The purpose of this chapter is to provide an overview of the use of language in the legal systems of each of the four selected countries. We specifically focus on the language of record in courts of law for each country and examine the relationship between legal professionals and litigants. Furthermore, the purpose is to assess whether linkages can be drawn between the linguistic competencies of legal professionals and the language of record; and if this affects the litigant's right to a fair trial and their language rights. For each country discussed here, we have engaged with the constitutional, legislative and policy developments in relation to the sociolinguistic make up and how, on a broader level, the country functions socially, politically, economically and, most importantly for the book at hand, linguistically. We will draw parallels between the international countries presented in this chapter in relation to the main model of South Africa, the core focus of this book. Chapters 2 and 3 are intended to serve as jurisprudential case studies that South Africa, with regard to language and law, could emulate or steer clear of.

\section{Australia's sociolinguistic landscape}

Australia only became one country in 1900. Up until this point, it was just a group of unfederated states or colonies (Cooke, 2019). Cooke (2019) makes this point given that the sociolinguistic make-up of Australia was influenced by the geographical positioning of the country. For example, the indigenous languages of Australia are not limited to the Aboriginal languages but include the languages of the Torres Strait Islanders (ibid). The languages of the Torres Strait Islanders are included owing to their geographical positioning where they occupy a number of islands at the tip of Queensland (Cooke, 2019). The Australian Institute of Aboriginal and Torres Strait Islanders Studies (AIATSIS), as part of the 2019 
International Year of Indigenous Languages, outlined the history of Aboriginal languages and the current plight of these languages. The AIATSIS reports that, at the time of the European settlement in 1788, more than 250 indigenous languages were spoken, and an additional 800 dialectal varieties existed. Although 100 of these indigenous languages are presently spoken, the languages are spoken only by elders in the communities and so risk extinction with the death of the elders (AIATSIS, 2019). The number of languages to be extinct is determined on the basis that a mere 13 indigenous languages are acquired by children (AIATSIS, 2019). That leaves the status of the remaining indigenous languages unknown and, in all probability, they also face extinction. Historically, the value of indigenous languages has been low with emphasis placed on English.

From the Federation in 1901 up until 1959, language was used as a tool by the Australian government to prohibit access to immigrants. This occurred in the form of the "White Australian Policy' enforced through the Immigration Restriction Act of 1901. The purpose of this Act (1901) was to prohibit immigrants from entering Australia due to the fact that they were unsuitable as a result of being Asian or of non-European race (Robertson, Hohmann \& Stewart, 2005:241). A key element of the Immigration Restriction Act (1901) was the dictation test (Robertson et al., 2005:241). The test administered to non-European immigrants was a test to examine their suitability to enter Australia (Robertson et al., 2005:242). Simply put, it was a racial test to prohibit non-White persons from entering. This racial test was administered in a language the aspiring immigrants did not understand to ensure the test was failed (Robertson et al., 2005:242). Section 3(a) of the Immigration Restriction Act (1901) defines a prohibited immigrant. In doing so, it highlights how language has been used to discriminate against people. Section 3(a) defines a prohibited immigrant as follows:

Any person who when asked to do so by an officer fails to write out a dictation and sign in the presence of the officer a passage of fifty words in length in a European language directed by the officer.

According to Robertson et al. (2005), "a European language” referred to English. We have advanced this discussion pertaining to the racial test as an example of how language and, in this case, English, has been used to exclude persons. It also highlights the dominance of English with a parallel which can be drawn with Afrikaans in South Africa during Apartheid, followed by English under the liberation movement.

According to Meakins (2015), there is also a culture of obliviousness in Australia regarding the existence of Aboriginal languages. Meakins (2015) explains that she often asks her linguistics students to name an Australian indigenous language and is met mainly with silence - most cannot manage to name even one. In a few instances, she points out that the students would name Warlpiri, Yolngu Matha or Arrente. The point is that, of 250 indigenous languages, linguistics students are only able to identity three. Meakins (2015) 
further states that, if she were to ask the students about indigenous American languages, they were able to identify these with ease, given their visibility through media forums. The same can be said of South Africa where a sense of economic and social utopia is created around the prospects of learning and speaking English as opposed to the African languages.

Crystal (2003:20) explained that introducing English or, in the case of Australia, a simpler version (pidgin), was not intended as a means to communicate with the indigenous people but as a means of conquest and assimilation. This had disastrous effects on the use and development of indigenous languages over time. According to Meakins (2015), there are presently initiatives in place to revitalise the indigenous languages through organisations and universities: Adelaide University has been tasked specifically with the revitalisation of Kaurna Warra Pintyanthi while the Victorian Aboriginal Corporation is tasked with revitalising the languages in Melbourne including signage in cities, the media and movies.

While we attended the 14th Biennial Conference of the International Association of Forensic Linguists in July 2019, the NAIDOC week 2019 was taking place. NAIDOC stands for the National Aborigines and Islanders Day Observance Committee which celebrates the history, culture and achievements of Aboriginal and Torres Strait Islander people. The week-long festivities are held annually in July across Australia. In 2019 we observed that there was a distinct emphasis placed on using indigenous languages in public spaces in Australia.

\section{Language of record: Australian English}

According to Cooke (2019), there is no specific constitutional or legislative provision that states what the language of record is in Australian courts. Regardless of the fact that there are state courts in each territory, the language of record across all courts is English. Bush courts also exist in Australia. These are circuit courts operating in remote areas to which magistrates from major centres travel to hear cases. We discuss three issues: firstly, we review what Australian English is and how it is used in courts of law; and, in doing so, we outline the advantages and disadvantages of using Australian English. Secondly, we discuss the disadvantage before the law for Aboriginal litigants and the system of interpretation for Aboriginal litigants. Thirdly, we discuss the Bush courts and the linguistic difficulties experienced therein.

Cooke (2009:27) advances that an Aboriginal learner's English differs from Standard Australian English and that this difference contributes to miscommunication. Aboriginal learners' first language heavily influences their acquiring of English. The differences in language are in pronunciation, grammar, semantics and pragmatics (ibid). Communication confusion is more prevalent with temporal reference, distance and other quantitative matters (ibid). This can be disastrous for a complainant, witness or accused, as time, facts 
and distance can be central to proving or disproving a charge. Cooke (2009:27) provides numerous extracts of examination in chief and cross-examination where the witness is an Aboriginal speaker of Australian English and miscommunication results, as per this example:

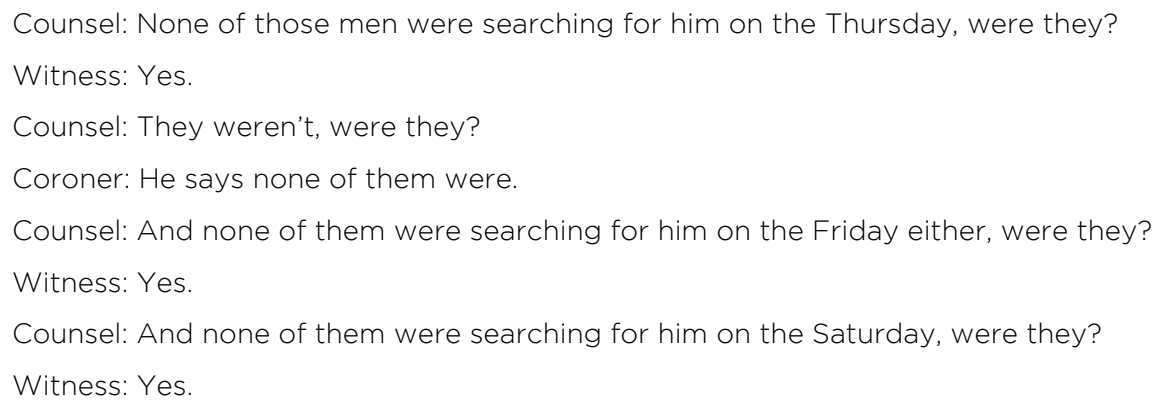

Cooke (2009:27) explains the excerpt as follows:

The witness here is responding to the proposition ("none of them were searching") rather than the tag ("were they?"). This is what he would do in his language. This was well into the case and the coroner had become accustomed to this feature of Aboriginal Learner's English, but counsel had not.

Most indigenous people from communities in remote areas of northern Australia do not speak English as their mother tongue (Cooke, 2009:26). A few indigenous people have a full command of English and many possess a minimal level of proficiency for basic communication skills in social settings (ibid). This is important to note for the proceeding sections of this discussion on Australia where Aboriginal speakers are disadvantaged by a legal system with an English language of record policy. This is also important to note in relation to Chapter 6 which comprises language surveys on the English language proficiencies of both litigants and attorneys in South Africa (De Vries \& Docrat, 2019).

The differences between Aboriginal English and Standard Australian English have been investigated for a number of years. Eades (1994) discusses these differences in English in the Australian legal system and makes several points that correlate with the work by Cooke (2009) presented above. Eades (1994:237) defines Aboriginal English as a name given to varieties of English spoken by Aboriginal people. The difference is not solely linguistic, but more sociocultural (Eades, 1994:240). Aboriginal people are not direct in their communication: through their indirectness, they avoid prying or asking direct, personal questions. Thus, their social and cultural patterns influence how they ask and answer questions. As Eades (1994:234) points out, this is disastrous in the legal setting. She provides a simple example similar to Cooke's (2009:27) one: An Aboriginal speaker would ask a question in this way: "You were at the pub", as opposed to, "Were you at the pub?" In Aboriginal English, an Aboriginal speaker's linguistic form is usually a statement with a rising intonation (Eades, 1994:240). 
Aboriginal English makes no gender distinction in the third-person pronoun; therefore, him is used to mean he or she (Eades, 1994:204). The same applies with isiXhosa in South Africa where there is no distinction between 'he' and 'she'; and isiXhosa mother tongue speakers who have limited English language competency often refer to the incorrect gender. This can have serious consequences in the legal setting, commencing with the police statement recording and then in court when providing evidence. Furthermore, Eades (1994) points out that, with Aboriginal English speakers' quantitative questions, such as 'when', 'where', 'who', 'how' and 'what', time is not responded to directly. If asked how many people were present, names will be provided rather than numbers. For example, 'What time did you witness the crime taking place?' may result in different answers. 'Before dark' can be any time in the afternoon (Eades, 1994).

Eades (1994) makes the important point that every person who does not have a legal background or some familiarity with the legal system (and specifically police interviews and courtroom questioning) are disadvantaged before the law. For speakers of Aboriginal English, this disadvantage is even greater, as language is a barrier and miscommunication is present in most instances. The work of Eades (1994) and Cooke (2009) will be drawn upon in Chapters 6 and 7, within the South African context, specifically drawing parallels with the language survey by Legal Aid South Africa (2017) and the language survey conducted with attorneys in South Africa on their communication with clients (De Vries \& Docrat, 2019).

What can be deduced from the discussion thus far is the disadvantage that exists in the legal system and how the indigenous people are placed at a disadvantage due to their limited English language competency: everything is measured according to Standard English which was essentially a foreign language before the colonisers arrived. This situation speaks to the relationship between language, law and power, to which our focus now turns.

\section{Disadvantage before the law: language and power}

The previous section of this chapter comprising the discussion on the language of record brings into focus the disadvantages faced by Aboriginal people in the Australian legal system. Language can be a barrier to accessing justice; and language can be used as a powerful tool to exclude people. Gibbons (1994:196) makes this profound assertion:

Simply providing the same treatment for everyone within the legal system may not ensure true justice, particularly if that treatment has emerged from the culture and interests of a power elite. Within the language sphere it may be important to recognise that there are people who are disadvantaged by their lack of mastery of the language through which the law is accessed and applied and/or by the discourse conventions of legal proceedings. 
This is an important assertion that brings into focus the difference between equal treatment and 'true justice'. Gibbons (2003:201) points out that, in courtrooms, the power vests with legal professionals and that this power is linguistic in nature. Gibbons (2003:205) specifically mentions the Aboriginal people and acknowledges the academic contribution made by Eades on the subject in highlighting the plight of Aboriginal people. The injustices suffered by Aboriginal people in courts was acknowledged in the year 2000 when the Magistrates' Courts of Victoria made a public apology (Gibbons, 2003:205). The power relations embedded in language within the courtroom are also highlighted by Gibbons (2003:207), who explains that Aboriginal witnesses are more inclined to answer 'Yes' when asked a question. Aboriginal witnesses agree in an effort to halt the line of further questioning (Gibbons, 2003:208). This, in a legal context, disadvantages the witness and brings into question the witness's reliability and, in effect, the admissibility of the evidence. Gibbons (2003:227) holds that it is the way in which language is used that disadvantages people. This form of disadvantage is exacerbated where people are already less powerful or disadvantaged in other ways, such as ethnic groups including the indigenous people (Gibbons, 2003:227). Gibbons (2003: 227) succinctly summarises this in the following excerpt:

These types of disadvantage, which have deep social roots, cannot be remedied only by linguistic means. However, there are measures that can be taken to improve the situation...just treatment does not mean the same treatment, but rather recognising difference, and developing measures to cope with these differences.

This excerpt must also be applied to the South African context where it is arguable that a monolingual language of record policy for courts does not address the disadvantages faced by African language speakers in South Africa, but rather attempts to apply a general Band-Aid that furthers the advantage of the English-speaking minority and socio-political elite. One measure which Gibbons (2003:221) recommends for Australia is "the additional resource - the interpreter and translator". Legal interpreting and translating for Aboriginal people in courts is the focus of the next part of this discussion.

\section{History and development of interpretation in Australia}

Thus far, the discussion on Australia has highlighted the issues of miscommunication in courts, where the problem is threefold. Firstly, there are the differences between Aboriginal English and Standard Australian English; secondly, social and cultural norms of Aboriginal people affect demeanour and, ultimately, the admissibility of evidence; and, lastly, there are the unequal power relations that favour persons' familiar with the legal context, specifically courtroom discourse, where language is used to exclude or mislead. These issues lead to one solution or possible way in which these issues can at least be minimalised - legal interpretation. We are specifically using the term 'legal interpretation' as there is a general misconception that a mother tongue speaker of a language can act as an interpreter. In 
Chapter 2 of this book, we advanced Article 14(3) of the International Covenant on Civil and Political Rights (1996) where persons are permitted:

(f) To have the free assistance of an interpreter if he cannot understand or speak the language used in court.

Article 14(3) (f), according to Gibbons (2003:238), relates directly to court interpreting and states that this service be free of charge. The service is extended to include the translation of all documents for court proceedings (Gibbons, 2003:238). One aspect of Article 14(3) (f) leaves open, for determination on a case-by-case basis, the level of comprehension and speaking ability necessary for an interpreter to be used (Gibbons, 2003:238). Cooke (2009:29) argues that it is questionable whether a Judge or a Magistrate is qualified to determine reliably the witness's English proficiency and that guidance is needed from an appropriately qualified linguist.

According to Goldflam (2012:2), the first recorded case in which an interpreter was used was in 1885 in Queensland. The Judge dismissed the case in which four men were charged with murder. The case was dismissed as no interpreter could be found to enable them to hear and understand what they had been charged with (Goldflam, 2012:2). With this case, justice had not run its course, especially for the victim's family. Goldflam (2012:2) explains that Australia does not have legislation addressing the use of interpretation. However, the country is a signatory to the International Covenant on Civil and Political Rights (1996) and thus needs to comply with the provisions of Article 14, advanced above.

Gibbons (1994, 2003), Eades (1994) and Cooke (2009) have documented instances in which interpreters have not been supplied for Aboriginal witnesses and accused persons and this remains an ongoing problem. MacFarlane, Kurt, Heydon and Roh (2019:51) argue that the provision of interpreters in Australian courts remains inadequate in both quantity and quality. There are instances in which qualified interpreters are available but are not used. This non-use of interpreters is indicative of the ideology that privileges English monolingualism and supresses the language rights and preferences of indigenous minorities (MacFarlane et al., 2019:51).

There are instances in which legal representatives decline the use of an interpreter for their clients where a Judge suggests this (Cooke, 2009:29). This is done in some instances as a matter of strategy so that the Judge is unable to understand the witness or accused. If employed, it is a dangerous strategy and fails to work. This will be seen in forthcoming chapters concerning the South African case law. Again, this speaks to Gibbons's (2003) earlier point about understanding what 'true justice' is. Cooke (2009:29) engages with Goldflam's (1995) earlier work that brings into question how the client communicates with the lawyer if interpretational services are declined; and how the attorney receives 
instructions from the client if there is a communication barrier. Some lawyers argue that interpreters complicate matters and that judges are then able to understand the proceedings better without interpretation for witnesses (Cooke, 2009:30).

Aboriginal people are courteous and will answer questions posed by White people in the way in which the questioner wants. Even if people are not courteous, there is the same reaction when they are dealing with an authority figure such as a policeman. Some Aboriginal people find the standard caution quite bewildering; even if they understand that they do not have to answer questions, this is confusing as, if they do not have to answer questions, then why are the questions being asked?

The use of interpreters in judicial proceedings is not standard practice but is influenced by whether the court is seated in a Federal state in Australia or follows the Common Law. The Common Law doctrine does not guarantee the right to an interpreter. However, an interpreter may be provided at the discretion of the judicial officer (Gibbons, 2003:238). In Australia, at Federal level, the 1995 Federal Evidence Act is applicable. Although this statute does not entrench the right to an interpreter for second language speakers, the judicial officer is compelled to justify why an interpreter was not employed in the proceedings (ibid). The onus is thus reversed and no longer falls on the witness to prove the need for an interpreter (ibid). This is not necessarily advantageous as there can be an instance in which the judicial officer does not recognise the need for an interpreter on the basis that the witness can speak English. This relates to previous points in this discussion, where judicial officers fail to recognise the disadvantage that Aboriginal speakers experience when communicating in English.

In south Australia the right to an interpreter is conferred through the Evidence Act Amendment Act 1986, which states the following:

14(1) Where

(a) the native language of a witness who is to give oral evidence in any proceeding is not English; and

(b) the witness is not reasonably fluent in English, the witness is entitled to give that evidence through an interpreter.

Gibbons (2003:239) focuses on the word "entitled" in this provision. This form of language in the provision is obligatory and guarantees a second language English speaker the right to an interpreter. Gibbons (2003:239) also highlights the phrasing, "reasonably fluent in English" as problematic, as it is discretionary: the determination of fluency is undertaken by the judicial officer who, according to Gibbons (2003:239), is most likely to be a monolingual English speaker with minimal or no knowledge of second language comprehension problems. This speaks to the importance of having linguists who can assess the competency of witnesses and the need for a more linguistically transformed legal system, not only in Australia but also in South Africa. 


\section{Legal interpreting and translation in Australia}

Our focus shifts to legal interpreting where parallels can be sought between the qualifications of interpreters. The following extract by Gibbons (2003:241) is of relevance and summarises the two issues of legal interpretation:

There are two issues in the supply of interpreters/translators. First the availability of bilinguals who have the potential to act as courtroom interpreters. The second issue is the quality of translators/interpreters - adequate legal interpreting demands the following special knowledge and abilities: a high level of proficiency in both languages; knowledge of regional variants of these languages used in local communities; good general knowledge; and knowledge of the following: professional ethics; the legal process and legal language; and courtroom/police discourse conventions.

Legal translators have more time to find equivalents that best describe concepts that are not directly translatable from English into the Aboriginal languages. Legal translators are given the text beforehand and are able to grapple with and find solutions to language non-equivalence. Legal interpreters do not have this luxury in court, especially with cross-examination.

In courtroom interpreting, two forms of interpreting can be identified: consecutive interpreting and simultaneous interpreting. Consecutive interpreting is "... where the interpreter waits until the speaker has finished a stretch of speech, usually a small number of sentences, then during a silent period left by the speaker, the interpreting takes place" (Gibbons, 2003:245). Simultaneous interpreting "is a specialised skill in which the interpreter interprets at the same time as the speaker is speaking, usually producing an interpreted version a few words behind the speaker." (Gibbons, 2003:245).

Judge Belinda Hartle (Hartle, 2019) refers to issues of consecutive interpretation where interpreters, in her experience, tend to summarise what the judicial officer is saying. A further point picked up from McConnachie (2019) is the issue of dialect of a language in court interpreting (see also Mbangi, 2019).

The point of departure is the important function of interpreters and translators in the legal system, especially within courtrooms where the judicial officer weighs the admissibility of evidence and a discrepancy between a police statement and viva voce evidence. The consequences may be disastrous for either the accused or the complainant.

\section{Interpreter qualifications in Australia}

The previous section highlights the importance of quality interpretation by qualified legal interpreters. In civil cases in the State of Queensland, the litigants are to engage an interpreter and pay for such services rendered. This is similar to South Africa where, in civil cases, regardless of the court's jurisdiction, litigants are to engage an interpreter and pay such costs (Hartle, 2019; Mbangi, 2019). 
In many Aboriginal communities in Australia an urgent need exists for interpreters in the legal system. However, obstacles are encountered where bilingual proficiency is not of a high level and educational levels are below what is required by standard certification of interpreters and translators (Gibbons, 2003:242). Gibbons (2003:242) questions, then, what level of justice the legal system is rendering to Aboriginal people and notes that these indigenous people are once again disadvantaged before the law.

It is also important for the interpreters to have a sound knowledge of the two cultures through which the interpretation is taking place as cultural terms are often difficult to transport through interpretation into another language whose speakers have their own culture. It was therefore a positive step by the Aboriginal Legal Service in 1970 to offer a legal aid service specifically for Aboriginal people who were essentially field officers that were competent cross-cultural interpreters (Eades, 1994:249-250). These services were employed for communication between Aboriginal clients and their legal practitioners (ibid). A parallel can be drawn with South Africa in relation to the case of State $v$ Pienaar (2000) where the court held that an interpreter must be provided for by the state when a client is relying on legal aid services and the legal professional cannot communicate directly with the accused.

A recommendation from the Commonwealth Attorney-General's Department report on access to interpreters in the Australian legal system (1991) was that a professional level of interpreter accreditation be a minimum standard for legal interpreters in any language (Cooke, 2009:32). The National Accreditation Authority mostly accredits indigenous language interpreters for Translators and Interpreters (NAATI) at the level of paraprofessional, which is described as:

- [Paraprofessional accreditation] represents a level of competence in interpreting for the purpose of general conversations, generally in the form of non-specialist dialogues.

Accreditation is achieved through individual testing where the pass mark is $70 \%$. Cooke (2009:32), who identifies himself as having conducted these tests, explains that there is a quality difference between the interpreter who obtains the minimum threshold pass of $70 \%$ and the other interpreters who achieve a test mark of 85\% and above. Cooke (2009:32-33) advances both sides of the coin, explaining that, in some instances, interpreters with a minimum pass mark, or those who have failed their accreditation, are used as legal interpreters in courts. The other side of the coin is that, in some instances, there are accredited interpreters who are exceptionally competent and highly proficient in both languages and are used as court interpreters (ibid). This links to an earlier argument by Gibbons (2003) in which he explained the need for skilled court interpreters who can interpret simultaneously and consecutively. Cooke (2009:33) goes on to explain that by the end of 2009, for the first time, three indigenous interpreters were accredited by NAATI as professional level interpreters. This is a positive sign that the primary service of interpretation is growing for high status domains such as the legal system. 
There is again a difference of interpretation of accreditation in different Australian states. The Northern Territory Aboriginal Interpreter Service had 300 registered interpreters, one quarter of whom were accredited (Cooke, 2009:33). According to Cooke, (2009:33), accreditation through the Northern Territory Aboriginal Interpreter Service could have been obtained through the completion of a Diploma in Interpreting which comprises a course of 300 hours offered through Bachelor Institute. The majority, however, have passed by completing short test preparation workshops over the course of a few days or a week, followed by taking NAATI's oral test.

A new development by the Judicial Council on Cultural Diversity (JCCD) is the Recommended National Standards for Working with Interpreters in Courts and Tribunals, a 132 page document from which we have extracted relevant sections. Part of the preamble summarises the intention of the recommended standards (JCCD, 2017:iv):

The interpreter's role is to remove the language barrier so that the party can be made linguistically present at the proceedings and thereby be placed in the same position as an English-speaking person. This means that a party is entitled to participate in the proceedings in their own language. As such, the work of interpreters is essential to ensuring access to justice and procedural fairness for people with limited or no English proficiency in Australia's courts. Further, in the case of criminal proceedings, if an accused is unable to afford an interpreter and an appropriate interpreter is not provided at the expense of the court or an agency of government, the trial cannot proceed unless and until an interpreter is provided.

This extract attempts to preclude any form of disadvantage before the law relating to language and prioritises the rights of indigenous people to ensure equal treatment as English speakers. There is also the commitment of providing interpretational services at the state's expense for criminal proceedings. Recommended standards for interpreters are clearly set out and are as follows:

Standard 18 - Interpreters as officers of the court

18.1 Interpreters are officers of the court in the sense that they owe to the court paramount duties of accuracy and impartiality in the office of interpreter, which override any duty that person may have to any party to the proceedings, even if that person is engaged directly by that party.

\section{Standard 19 - Court Interpreters' Code of Conduct}

19.1 Interpreters must ensure that they are familiar with, and comply with, the Court Interpreters' Code of Conduct.

Standard 20 - Duties of interpreters

20.1 Interpreters must diligently and impartially interpret communications in connection with a court proceeding as accurately and completely as possible.

20.2 Interpreters must comply with any direction of the court. 
20.3 Where the interpreter becomes aware that she or he may have a conflict of interest, the interpreter must alert the court to the possible conflict of interest immediately, and if necessary withdraw from the assignment or proceed as directed by the court.

20.4 Requests by the interpreter for repetition, clarification and explanation should be addressed to the judicial officer rather than to the questioning counsel, witness or party.

20.5 There may be occasions when the interpreter needs to correct a mistake. All corrections should be addressed to the judicial officer rather than to the questioning counsel, witness or party.

20.6 If the interpreter recognises a potential cross-cultural misunderstanding, or comprehension or cognitive difficulties on the part of the person for whom the interpreter is interpreting, the interpreter should seek leave from the judicial officer to raise the issue.

20.7Interpreters must keep confidential all information acquired, in any form whatsoever, in the course of their engagement or appointment in the office of interpreter (including any communication subject to client legal privilege) unless:

a. that information is or comes into the public domain; or

b. the beneficiary of the client legal privilege has waived that privilege.

These provisions regulate the practice of interpreters in Australian courts with an emphasis placed on accurate interpretation, speaking to the issue of quality of interpretation. Section 18.1 is strengthened in Sections 20.1, 20.4 and 20.5 that speak to diligence and the ability of an interpreter to ask for repetition, clarification and explanation where necessary in order to avoid a mistake and correct where necessary. This is important in ensuring quality interpretation and procedural fairness for all parties concerned. With reference to procedural fairness, the interpreter is to be impartial; where there is a conflict of interest, this must be made known, and the interpreter removed where necessary. An interesting inclusion was Section 20.6 concerning cross-cultural communication and its effect on cognition and comprehension.

As is seen thus far with the Australian case study, there are dialectal differences that are embedded in cultural communities amongst the Aboriginal people, and a miscommunication could have disastrous effects. The Recommended National Standards for Working with Interpreters in Courts and Tribunals document is extensive in its mandate and is a positive step towards regulating the profession of interpreters in Australia. The Recommended National Standards for Working with Interpreters in Courts and Tribunals document will also be important in the context of South Africa. Such a comprehensive document is absent there, yet the Heads of Court, through the monolingual language of record policy, have directly elected to operate a legal system where the majority of litigants and witnesses cannot speak, understand, read or write English.

MacFarlane et al. (2019) have argued that, although attempts have been made to regulate interpretation services in Australia, it remains an unequal system through which Aboriginal people are subjected to either low levels of interpretation or non-availability 
of an interpreter. The former relates to the low levels of qualifications where no tertiary qualification is needed to be a legal interpreter (MacFarlane et al., 2019:56-57). The latter relates to the fact that there is no guaranteed right to an interpreter. This is compounded by the judicial view of the lack of importance of interpreters for Aboriginal people. MacFarlane et al. (ibid, 56) substantiate this point by drawing on a statement made by then Chief Minister, Dennis Burke, before the introduction of the Aboriginal Interpreter Service in the Northern Territory in 2000. He said: "Providing Aborigines with interpreters was like giving a wheelchair to someone who should be walking."

This harrowing statement lays bare the treatment of indigenous people by a justice system tasked with impartiality, procedural fairness and equality before the law. It must be questioned, in the South African context, if this is not also the thinking and reasoning behind a monolingual language of record policy that excludes the majority of people on grounds of language. We engage further with this point in the forthcoming chapters of this book.

\section{An Aboriginal interpreter's perspective of language in the courts}

An online news article, Joyner (2018) provides practical examples of the difficulties Aboriginal people face in the Australian legal system. The article focuses on the area of Kalgoorlie, where surrounding remote areas have magistrates flying in to the Bush courts. The level of justice is always questionable, given that a Magistrate can hear up to 100 cases in a day (Joyner, 2018). One can question how much, if any, interpreting takes place in these courts, where interpreting is often time-consuming. Joyner (2018) reports that interpreters have a difficult time with interpretation as accused persons are always frightened by the daunting legal processes and appear to agree with everything or speak in hushed tones.

This is the case, according to Stubbs who acts as a guide for Aboriginal people navigating their way through the system. Although Stubbs has no formal training as an interpreter, he has become accustomed to interpretation through his 30 years' experience working for the Aboriginal Legal Service in Kalgoorie, a Legal Aid organisation based in Perth and 14 surrounding towns (Joyner, 2018). Stubbs, who interprets for Wongatha Aboriginal speakers, does not charge Aboriginal people and is one of many offering this service free of charge (Joyner, 2018). Stubbs has assumed the title of court officer, comprising the roles of interpreter, advisor, negotiator and fixer given that interpretation in these areas is more than merely acting as a third-party communicator (Joyner, 2018). In the news article, Joyner (2018) alerts us to the actual plight of indigenous speakers and their marginalisation from Australia's courts in which linguistic discrimination is a daily occurrence. Deanne Lightfoot, the Chief Executive Officer of the Aboriginal Legal Service in Kalgoorlie, has reported that there is an Indigenous Interpreters Project underway in the Goldfields region of Australia to increase the numbers of interpreters and train them to deal effectively with these cases in ensuring equal access to justice and procedural fairness (Joyner, 2018). 
Through the sociolinguistic discussion, it is clear that, as with South Africa, Australia has a rich language history of many indigenous languages. As is the case with many countries across the globe, these indigenous languages are dying and many more face extinction. The death of languages lies with the fact that languages are not used in high status domains and are therefore not developed by the state and used as languages of learning and teaching. Through the work of Meakins (2015), the Australian case study illustrates that younger generations are unable to speak or identify their indigenous languages. A culture has been created which Crystal (2003) describes in terms that reflect a sense of the global rise of English, along with the death of all other languages.

Language has served as a tool of politicisation, marginalisation and discrimination commencing with the colonisers' arrival in Australia. This politicisation has resulted in a further distinction and growing inequality between Aboriginal people and White Australians through Standard Australian English and Aboriginal English. The theme of language and power is evident where Aboriginal people are seen as less powerful and are ultimately disadvantaged in courts as a result of language barriers.

Drawing on the works of Eades (1994) and Gibbons $(1994,2003)$, it is evident that the cross-cultural communication impasses are overlooked in many instances, resulting in innocent persons being found guilty and sentenced, or the guilty being acquitted. These cross-cultural communication problems are not unique to the courtroom, as the discussion shows, but commence with the police services. Cooke (2009) has presented the many issues facing interpretation in Australian courts. These are compounded by the fact that there is no guaranteed right to interpretation in those courts. In a multilingual country such as Australia where the language of record is English, it is problematic not to have interpretation services that are of high quality and readily available. The matter is further compounded by the fact that the 'legal system' does not inherently recognise the importance of interpretation. Through the work of Joyner (2018), the Australian case study also highlights that the problems are practical and that there are no effective policies and initiatives addressing the continued disadvantage and discrimination endured by Aboriginal persons in the legal system.

\section{Belgium's sociolinguistic landscape}

Belgian linguistic history has been influenced by cultural, nationalist, political and economic power battles between the Dutch and the French. Although the Dutch were the majority group in Belgium, they felt threatened by the French and the dominance of the French language. The Dutch thus opted to support legal provisions that constrained the use of language, rather than opting for freedom of language use (Wynants, 2001:43). This favoured the adoption of the principle of territoriality. With the principle of territoriality in Belgium, one language is only officially recognised within a given territory (Wynants, 2001:43). 
In 1840, the Dutch realised that there was not exclusive use of Dutch, as had been anticipated with the principle of territoriality. A petition was launched to denounce language discrimination in Belgium (Wynants, 2001:45). In 1859, a Commission of Grievances took up the same protests and demands recorded in 1840 (Wynants, 2001:45). The Commission failed to recommend the exclusive use of Dutch in the Flemish provinces and ordered instead that official documents be translated and be made available in both languages (Wynants, 2001:45).

Belgium is divided into four language areas, namely the Dutch linguistic area, the French linguistic area, the German linguistic area, and the bilingual capital of Brussels (Boes \& Deridder, 2001:49). Within each area, the regional language is the sole official language with the exception of Brussels where French and Dutch are equally treated as official languages (Boes \& Deridder, 2001:49). When choosing between the principle of territoriality and personality, a sociopolitical consideration determines the outcome. Wynants (2001:47) explains that the principle of personality implies greater freedom of individual choice and is therefore considered democratically sound. The principle of territoriality constricts freedom and imposes constraint and forced assimilation (Wynants, 2001:47). Selecting between either of the two principles is determined by material and financial factors relevant to the country or the area in which the language policy is to be applied (Wynants, 2001:47).

The current Belgian sociolinguistic landscape has been influenced and regulated by a number of constitutional and legislative enactments. These developments are identified and discussed in the following sections of this chapter.

\section{Constitutional and legislative language enactments}

The Belgian Constitution provided that the use of the official languages in Belgium was optional and that only legislation could regulate the use of the official languages for public authorities and legal matters (Boes \& Deridder, 2001:49). In accordance with this provision, the Law of June 15, 1935 was enacted. This Law was comprehensive in that it replaced a number of previous statutes governing the use of language in the judiciary from 1889 to 1908 (Wynants, 2001:46). The replaced legislation included, but was not limited to, the first language legislation in Belgium, namely the Law of August 17, 1873, Moniteur Belge, 43, 238 and the Law of August 26, 1873. The Moniteur Belge, 43, 238 legislation dealt with language use in the judiciary and conferred a right upon Flemish accused persons to use Dutch in criminal proceedings (Wynants, 2001:45). The Moniteur Belge, 43, 238 was a significant victory for the Flemish in Belgium given that, in 1860, Flemish workers had minimal knowledge of French. If they were subsequently tried in French for murder, they were found guilty and executed (Wynants, 2001:45). It later transpired that the Flemish workers were innocent, proving that language barriers were the cause of the execution 
(Wynants, 2001:45). The Law of June 15, 1935 therefore needed to address the linguistic deficiencies in creating a more linguistically just and equal legal system. The purpose of the Law of June 15, 1935 was two-fold:

1. The law applies for judgments and procedural acts; and

2. The law sets out rules to determine the language used by the court, as well as before the court.

It is evident that the Law of June 15, 1935 regulates proceedings in terms of the language competencies of judges and the language(s) to be used in delivering judgments. Moreover, the Law of June 15, 1935 determines the language in which proceedings are to be conducted and the subsequent language of record. The use of language in court is determined through different criminal and civil procedures, as outlined by the Law of June 15, 1935. Boes and Deridder (2001:51) explain that, through the implementation of the provisions in the Law of June 15, 1935, there might be an implication of derogation from the territorial linguistic competence of courts.

\section{Language of record in the Belgian criminal justice system}

Criminal proceedings can only be initiated following the conclusion of a criminal investigation that commences with a charge or complaint laid with the police. Thus, the criminal investigation is an important process in capturing the relevant information and evidence needed to prosecute the accused person. Language is instrumental in this process where communication between the complainant and police officer provides the foreground to the investigation, as is the questioning of the arrested person by the police. The linguistic issues plaguing the South African Police Service (SAPS) and, in some cases, directly affecting the outcome of a criminal trial, have been discussed by Docrat et al. (2017b). The South African perspective is discussed further from Chapter 4 onwards. Reverting to the Belgian context, Article 12 of the Law of June 15, 1935 provides that "members of the Public Prosecutor's Department and the investigating officers must use the language of the court". With the territoriality principle implemented in Belgium, Dutch will be used in a Dutchspeaking area and French will be used in a French-speaking area. In Brussels, either French or Dutch can be used, depending on the language of the suspect.

Article 12 clearly states that the police officer must record the complainant's statement in the language of the said complainant or witness where the police officer has sufficient knowledge of this language. Where the police officer has insufficient knowledge, an interpreter has to be called to record the statement. Article 12 ensures complainants and suspects have access to linguistically competent police officers who can record their statements without any issues of linguistic barriers; if there are such barriers present, interpreters are available to assist. This point will be juxtaposed with the South African context in Chapter 5 where the SAPS draft language policy (2015) is advanced and critiqued with practical examples are 
provided. What is significant about Article 12 is that the importance of language is outlined from the beginning; and that professional interpreters are available for both the police and Public Prosecutor's Department.

At trial stage, it must be noted that only in exceptional cases will the language law assign a case to a specific court. Nonetheless, according to Boes and Deridder (2001:52), in criminal proceedings, territorial competence of criminal courts is determined through the following criteria:

- the location where the crime was perpetrated;

- the usual residence of the accused, if he or she is a natural person; and

- the present location of the accused.

These three factors resemble those of the South African model when determining jurisdiction for prosecution.

In criminal courts of the first instance, trials are conducted in Dutch, French or German, depending on the area in which the court is seated. The judgment is then also written and delivered in the language in which the trial was conducted.

Article 23 of the Law of June 15, 1935 holds that, where an accused person can only express him- or herself in one of the three languages, and as such does not understand the language of the court, he or she can request to be tried in the nearest court in a language of his or her preference (Boes \& Deridder, 2001:53). The Judge can refuse the request if of the view that the accused has sufficient linguistic competency, or it would be harmful to the proceedings. In instances of refusal, an interpreter will be provided for the accused (Boes \& Deridder, 2001:53). Article 23 will be compared to Section 35(3) (k) of the South African Constitution. As evidenced in Part One of Chapter 6, South African accused persons will be solely reliant on an interpreter where they do not understand or speak English. There is no recourse for a request for another court to hear the trial, as all courts have an Englishonly language of record policy in place.

\section{Language of record in the Belgian civil system}

The civil system mirrors the criminal justice system with regard to language and so similarities are evident. Commencing civil litigation requires a summons to be filed and served on the defendant. According to Articles 7 and 38 of the Law of June 15, 1935, the writ of summons has to be drawn up in the language of the area (Boes \& Deridder, 2001:54). There is no alternative to these provisions where the defendant is not able to ask for the writ of summons to be produced in another language. In the bilingual case of Brussels, the writ of summons can be drawn up in either Dutch or French, with the plaintiff choosing between the two. 
The defendant has the option of requesting that the language of proceedings be changed where he or she has insufficient knowledge of the language (Boes \& Deridder, 2001:54). There is also the option of both parties to litigation changing the language of proceedings through common agreement (Boes \& Deridder, 2001:54). Individuals appearing before a judicial officer are not restricted to using one of the three national languages as an interpreter can be provided (Boes \& Deridder, 2001:54). Judicial officers and lawyers are, however, bound to the language of the proceedings (Boes \& Deridder, 2001:54).

As with criminal cases, civil cases are assigned on the basis of territorial competence which is determined according to Article 624 of the Code of Civil Procedure. The court is chosen by the plaintiff from among the following four possibilities (Boes \& Deridder, 2001:54):

- the court in the municipal area of the residence of the defendant or one of the defendants;

- the court where the legal obligations arose or were executed;

- the court mentioned in the contract; and

- the court where the bailiff met the defendant in person if the defendant has no residence in Belgium.

The Belgian Court of Appeal and SC conduct proceedings in the same language used in the court of first instance. In Chapter 5, we advance the relevant provisions of the Magistrates' Courts Act (1944) and Superior Courts Act (2013). Suffice to say, at this stage of the discussion in relation to Belgium, South African legislation fails to confer language rights or any language protection on civil litigants; by default, all proceedings must be conducted in English. Furthermore, unlike the Belgian model, civil litigants in South Africa have to draw up the summons in English and cannot collectively decide to change the language of proceedings. Belgium goes as far as providing interpreters for those who do not have sufficient knowledge of the language of proceedings. In South Africa, in civil cases, the state provides no such service at their expense. Private interpreters can be hired and the costs be borne by the litigant or witness.

\section{Language competency of Belgian judicial officers}

By adopting the territorial principle there would need to be courts and public offices in each area fully functional in one of the three national languages. This, in turn, would require persons who are linguistically competent in the language(s) to staff these offices and courts. There was a need to establish Dutch universities to heed the requirement of having courts operating through the medium of Dutch (Wynants, 2001:46). Lawyers, magistrates and judges all received their education in French and therefore had minimal knowledge of Dutch in legal matters (Wynants, 2001:46). The problem was deep-rooted in that there was no professional literature in Dutch, nor was there any jurisprudence, textbooks, codes, law commentaries or teaching material in Dutch. 
Dutch terminology and other relevant material were available from the Netherlands, however, there remained the problem of staffing the Dutch universities (Wynants, 2001:46). A few Flemish lawyers and private individuals began with translation, interpretation and teaching on a part-time basis. In 1923, the Belgian government established an official commission tasked with translation. The first Dutch-speaking university was established in Ghent in 1930 along with the establishment of training schools for translators and interpreters (Wynants, 2001:47). The Belgium model follows the principle that the basic priority of a judiciary must be equality between all parties to litigation (Wynants, 2001:47). What is important is that each party to court must at least be able to understand the judges and magistrates and to be understood by them as far as possible with the support of translators and interpreters (Wynants, 2001:47).

Following the inherent principles of understanding, judicial officers and being understood by judicial officers is now regulated by appointments to the bench. Simply put, a person cannot be appointed to the bench as a Judge in a specific language area if he or she does not have sufficient knowledge of the language in the area (Boes \& Deridder, 2001:54). This knowledge is determined by the language of the candidate's law degree independent of their mother tongue (Boes \& Deridder, 2001:54). For example, if a candidate is a French mother tongue speaker but obtained their law degree in Dutch (Boes \& Deridder, 2001:54), they will be appointed to a court in a Dutch-speaking area, or in Brussels, since it has bilingual provision. The candidate thus has the requisite legal and academic proficiency in the language in which they graduated. A university degree in a specific language is not the requirement to attest to knowledge in that language but rather an additional examination to test their linguistic knowledge (Boes \& Deridder, 2001:55). This is especially the case for German mother tongue speakers as there is no German university in Belgium and therefore proficiency is tested through an examination (Boes \& Deridder, 2001:54). In Brussels, judgeships are allotted to French- and Dutch-speaking judges according to the various caseloads in the courts. There are minimum requirements for the composition of the bench in Brussels comprising the following: one-third of the bench must hold a diploma in Dutch; one-third must hold a diploma in French; and two-thirds of the bench must have a proven knowledge of their second language (Boes \& Deridder, 2001:55). In the court of Cassation, an equal 50/50 representation between Dutch and French-speaking judges is required, with all having a knowledge of German as a requirement (Boes \& Deridder, 2001:55).

The Belgian model illustrates the inherent emphasis placed on language and the human and financial support garnered towards the attainment of linguistic equality for all in Belgium. It is interesting to note the language requirements conferred on judges prior to their being appointed to the bench. This will be contrasted with the legislation relevant to attorneys, advocates, magistrates and judges in South Africa, advanced in Chapters 5 and 8 where, in South Africa, judges and legal practitioners have argued that judges 
cannot be 'shopped for' on the basis of language (Thulare AJ in State v Gordon, 2018) as this amounts to unfair discrimination. The foregoing discussion on Belgium also brings to the fore the important role that universities have in educating legal professionals, not only in the sense of their acquiring legal knowledge, but also the language in which this knowledge is acquired with separate linguistic communicative skills in a language that may not necessarily be the students' mother tongue. This speaks to the bilingual proficiency with which students graduate from Belgian universities and will be juxtaposed with, firstly, the growing trend of South African universities to adopt English-only language policies and, secondly, the endorsement by the South African judiciary that monolingual language policies are transformative and all-inclusive.

The Belgian model illustrates that, with human investment, commitment and financial capital, a system can be transformed to ensure an inclusive legal system that provides meaningful effect to litigants' language rights. From the onset of accessing the criminal justice system with reference to the police, both a complainant and accused are not disadvantaged by language. The Belgian model also importantly illustrates the role of universities in giving effective meaning to courts' language policies. It is interesting to note how universities and individuals are committed to the lexical development of each of the three languages in Belgium to ensure that academic texts are produced, and that translation of documents and sources of law are available in all three languages. This point will be juxtaposed with the South African context in Chapters 8 and 9 with reference to the work of Murray (2019) who advocates for universities to teach all content in English and only offer degrees through the medium of English; and where acquiring a second language, namely an African language, is seen as time wasted.

The recognition conferred on language and understanding of proceedings in the civil system is one that can be emulated and will be discussed in Chapters 6 and 7 with reference to the South African model.

The territoriality approach in Belgium is not without its problems, as outlined in the historical sociolinguistic perspective. However, the model is inclusive and does not problematise language in the legal system, instead viewing it as a right and a resource for dealing with practical problems as they arise.

What follows in the next section of this chapter is a discussion of Canada's model and the use of language therein.

\section{Canadian sociolinguistic landscape}

As established through the Founding Constitution Act of 1867, Canada represents itself as a bilingual state comprising French and English speakers. However, it has been noted 
that many citizens are monolingual and can only speak one of the two languages. Williams (2012:47) states that these monolingual citizens are primarily French speakers. From a historical perspective, the Canadian State's Founding Constitution Act of 1867 conferred upon all persons the right to "... use English and or French in courts and Legislative Assemblies of the Federal government and the province of Quebec". Doucet (2012:162) explained that Section 133 of the Constitution Act of 1867 was the only provision therein which dealt exclusively with language rights. Doucet (2012:162) states further that Section 133 was never intended to establish two official languages in Canada but rather to create what he termed an "... embryonic form of official bilingualism ..."

A parallel can be drawn with the South African model, discussed in Part One of Chapter 6 of this book, where Lourens (2012) refers to Section 6(4) of the Constitution as the "unborn" language legislation and the effects of a "delayed" birth. French assumed a subordinate position in government and parliamentary processes.

In the 1960s, Prime Minister Trudeau established a Royal Commission on Bilingualism and Biculturalism. The Commission's report in 1969 included a 'blueprint' for a bilingual language policy. The central theme of the report and, more specifically, the policy, was the "strengthening" and reaffirmation of bilingualism (Williams, 2012:47). It housed the objectives and principles upon which the Official Languages Act of 1968 was drafted and later enacted in 1969 (Williams, 2012:47).

The Belgian commission established in 1923 was tasked with translation of texts, legislation and other sources into Dutch. Although the Belgian and Canadian commissions had different objectives, they both illustrate the investment which these countries made into the development of their languages and for citizens to access a legal system in their mother tongue. This can be counterposed with the South African historical perspective which we will outline in the forthcoming chapters on South Africa where, following the CODESA talks, there was no government initiative to establish and follow through with the development of the nine African languages, nor the commitment of resources for the translation of important texts and legislation. This remains a contentious issue in South Africa, given the ongoing litigation (Lourens v Speaker of the National Assembly and Others, 2015; Lourens v State Party: Republic of South Africa, 2018) in which parliament has inherently argued that the Constitution does not compel that all legislation be translated into all 11 official languages.

The Canadian Official Languages Act of 1969 took significant linguistic strides providing for the establishment of language rights for both official languages (Williams, 2012:47). The relationship between citizens and the state more broadly was explicated with pronouncements on rights and duties of both the citizens exercising their language rights and the state, as well as state institutions in responding to these (Williams, 2012:47). The 
Canadian Official Languages Act of 1969 must be borne in mind in Chapter 5 of this book where we have advanced the objectives of the South African Use of Official Languages Act (2012) and commented on the provisions thereof. The Languages Act 2012, unlike the Canadian Official Languages Act of 1969, provides no further interpretation or protection of rights beyond the skeletal framework of Section 6 of the Constitution. In reality, however, the provisions of the Canadian Official Languages Act of 1969 were not implemented; and the languages and speakers thereof were not treated equally. Williams (2012:48) advanced that clarification needed to be sought on the parameters of the language rights; and, in establishing these parameters, the obligation of the state was to be outlined in ensuring the realisation of the language rights.

There was a proclamation of the Canadian Charter of Rights and Freedoms in 1982 heeding this call (published online as 'Constitution Act, 1982'). The Canadian Charter of Rights and Freedoms (1982) is the reaffirmation of the core principle of linguistic duality (Williams, 2012:48). Linguistic duality refers to the equal status and treatment of the languages. This again can be counterposed with the provisions in Section 6 of the South African Constitution. The term 'linguistic duality' is absent; instead, Section 6(2) calls for the elevation of the nine African languages. Although Section 6(2) is qualified through Section 6(3), obligating the state to use at least two languages, the minimum standard built in does not guarantee the elevation of the African languages.

There are many sections in the Canadian Charter of Rights and Freedoms (1982) dealing primarily with language:

16. (1) English and French are the official languages of Canada and equality of status and equal rights and privileges as to their use in all institutions of the Parliament and government of Canada.

(2) English and French are the official languages of New Brunswick and have equality of status and equal rights and privileges as to their use in all institutions of the legislature and government in New Brunswick.

(3) Nothing in this Charter limits the authority of Parliament or a legislature to advance the equality of status or use of English and French.

16.1 (1) The English linguistic community and the French linguistic community in New Brunswick have equality of status and equal rights and privileges, including the right to distinct educational institutions and such distinct cultural institutions as are necessary for the preservation and promotion of those communities.

(2) The role of the legislature and government of New Brunswick to preserve and promote the status, rights and privileges referred to in subsection (1) is reaffirmed.

17. (1) Everyone has the right to use English or French in any debates and other proceedings of Parliament.

(2) Everyone has the right to use English or French in any debates and other proceedings of the legislature of New Brunswick.

18. (1) The statutes, records and journals of Parliament shall be printed and published in English and French and both language versions are equally authoritative. 
(2) The statutes, records and journals of the legislature of New Brunswick shall be printed and published in English and French and both language versions are equally authoritative.

19. (1) Either English or French may be used by any person in, or in any pleading in or process issuing from, any court established by Parliament.

(2) English or French may be used by any person in, or in any pleading in or process issuing from, any court of New Brunswick.

20. (1) Any member of the public in Canada has the right to communicate with, and to receive available services from, any head or central office of an institution of the Parliament or government of Canada in English or French, and has the same right with respect to any other office of any such institution where

a. there is a significant demand for communications with the services from that office in such a language; or

b. due to the nature of the office, it is reasonable that communications with and services from that office be available in both English and French.

(2) Any member of the public in New Brunswick has the right to communicate with, and to receive available services from, any office of an institution of the legislature or government of New Brunswick in English or French.

21. Nothing in Sections 16 to 20 abrogates or derogates from any right, privilege or obligation with respect to the English and French languages, or either of them, that exists or is continued by virtue of any other provision of the Constitution of Canada.

22. Nothing in Sections 16 to 20 abrogates or derogates from any legal or customary right or privilege acquired or enjoyed either before or after the coming into force of this Charter with respect to any language that is not English or French.

As seen from these excerpts, the Canadian Charter of Rights and Freedoms (1982) is progressive and, according to Doucet (2012:162), heralded in a new era for the recognition of linguistic constitutional rights. Section 16(1) speaks to the principle of linguistic duality by stating that both French and English enjoy equality of status and equal rights and privileges. This speaks to the earlier point we made with reference to the case of Lourens v Speaker of the National Assembly and Others (2015) where Parliament argued that the South African constitutional provisions do not explicitly state nor imply that the languages enjoy equality, but should rather be treated equitably and used where practicable. Thus, Section 18(1) of the Canadian Charter of Rights and Freedoms (1982), advanced above, by stating that statutes and other relevant texts be made available in both languages is foreign to the mindset in South Africa where this is seen as impractical. Section 18(1) resembles the Belgian model, presented earlier in this chapter, where all statutes and texts were translated to ensure all speakers of the national languages have equal access. A further similarity with the Belgian model can be found in Section 16.1(1) where speakers of both French and English have the right to their own distinct universities: in Belgium, universities were established and law degrees are offered through the medium of one of the national languages. Again, this is different to South Africa: in Chapters 1 to 9, we advance the language policies of universities and the relevant litigation reaffirming English-only policies of teaching and learning (AfriForum and Another v University of the Free State, 2018). 
One point of critique, though, is that the Canadian Charter of Rights and Freedoms (1982) focuses on the Province of New Brunswick, a focus that will also be apparent in the legislation advanced below. Simply put, the other Canadian provinces are not as advanced, from a language rights perspective. Canada still has to ensure implementation takes place across all its provinces.

\section{Legislation: Official Languages Act of Canada}

As with any constitutional framework, legislation is required to provide elucidation and practical effect to the constitutional provisions. The Official Languages Act of Canada, (1988) is the primary language legislation of Canada. According to Williams (2012:48), the Official Languages Act of Canada (1988) reaffirms the importance of linguistic duality; and in doing so, emphasises the importance of language equality. Linguistic equality is thus entrenched through the Official Languages Act of Canada (1988) in "... Parliament; within the government of Canada; the federal administration and all institutions subject to the Act" (Williams, 2012:48).

The Official Languages Act of Canada (1988) provides that both English- and Frenchspeaking citizens can access all government services in a national language of their choice. According to Williams (2012:50), the Official Languages Act of Canada (1988) comprises three main objectives:

1. The equality of English and French in Parliament within the government of Canada, the Federal administration and institutions subject to the Act;

2. The preservation and development of official language communities in Canada; and

3. The equality of English and French in Canadian society.

It is our opinion that the Official Languages Act of Canada (1988) gives practical meaning to the Canadian Charter of Rights and Freedoms by obligating government and all state entities to provide services to citizens in the national language of their choice. By doing so, the languages are treated and used equally.

Thus far, the Canadian constitutional and legislative frameworks have not made mention of the legal system. To this end, what follows is a presentation of the New Brunswick Official Languages Act, (2002) regulating the use of language in the legal system and the language of record.

\section{Language of record in Canadian courts: The New Brunswick Official Languages Act}

The New Brunswick Official Languages Act (2002), focusing specifically on the legal system, was enacted in accordance with the provisions of the Canadian Charter of Rights and 
Freedoms (1982). This is evident from the Preamble. Sections 16 to 26 of the New Brunswick Official Languages Act (2002) comprise provisions dealing with the language of record and, more generally, language use in courts. These provisions read as follows:

16 English and French are the official languages of the courts.

17 Every person has the right to use the official language of his or her choice in any matter before the courts, including all proceedings, or in any pleading or process issuing from a court.

18 No person shall be placed at a disadvantage by reason of the choice made under section 17.

19 (1) A court before which a matter is pending must understand, without the assistance of an interpreter or any process of simultaneous translation or consecutive interpretation, the official language chosen under section 17 by a party to the matter.

(2) A court before which a matter is pending must understand both official languages, without the assistance of an interpreter or any process of simultaneous translation or consecutive interpretation, if both English and French are the languages chosen by the parties to the proceedings.

20 (1) A person who has alleged to have committed an offence under an Act or a regulation of the Province or under a municipal by-law has the right to have the proceedings conducted in the language of his or her choice and shall be informed of that right by the presiding Judge before entering a plea.

(2) A person who is alleged to have committed an offence within the meaning of subsection (1), has the right to be understood by the court, without the assistance of an interpreter or any process of simultaneous translation or consecutive interpretation, in the official language chosen by the person.

21 Every court has the duty to ensure that any witness appearing before it can be heard in the official language of his/her choice and upon the request of one of the parties or the witness, the court has the duty to ensure that services of simultaneous translation or consecutive interpretation are available to the person who made the request.

22 Where Her Majesty in her right of the Province or institution is a party to civil proceedings before a court, Her Majesty or the institution concerned shall use, in any oral or written pleadings or any process issuing from a court, the official language chosen by the other party.

23 Where the parties to civil proceedings, other than Her Majesty in right of the Province or any institution, do not choose or fail to agree on the official language to be used in proceedings, Her Majesty or the institution concerned shall use such official language as is reasonable, having regard to the circumstances.

24 (1) Any final decision, order or judgment of any court, including any reasons given therefore and summaries, shall be published in both official languages where:

(a) it determines a question of law of interest or importance to the general public, or

(b) the proceedings leading to its issuance were conducted in whole or in part in both official languages.

(2) Where a final decision, order or judgment is required to be published under subsection (1), but is determined that to do so would result in a delay or injustice or hardship to a party to the proceedings, the decision, order or judgment, including any reasons given, shall be published in the first instance in one official language and, thereafter, at the earliest possible time, in the other official language. 
25 All decisions of the Court of Appeal are deemed to fall within the scope of Section 24.

26 Sections 24 and 25 shall not be construed so as to prevent the pronouncement of a judgment, in either official language and in such a case, the judgment is not invalid by reason only that it was pronounced in one official language.

Section 16 pronounces both English and French as the languages of record in Brunswick courts. From the onset, it is clear that the languages of record for courts is in line with the Canadian official languages. Thus, for practical purposes, both languages are treated equally. Section 17 of the New Brunswick Official Languages Act (2002) is more advanced than Section 35(3) (k) of the South African Constitution in that litigants have a language right of choice in any matter (see Part One of Chapter 6 for a full discussion of the South African context). In the provision, emphasis is on the language used, referring to a "language of choice" as opposed to the South African context where the phrase "a language the accused understands" is used. This is extended to civil cases as well, where Section 22 provides that Her Majesty (the state) use the language chosen by the other party when communicating in any oral or written pleadings. Where parties excluding Her Majesty (the state) are parties to litigation and cannot agree on the language of record, Her Majesty (the state) will determine the language taking into account what is reasonable in the circumstances. These provisions are profound and afford language rights to civil litigants, as opposed to the situation with the South African model where Judge Hartle (2019) explained that proceedings are in English and interpretational services are not provided at the state's expense. These costs, Judge Hartle (2019) explains, may be too high as there is no quantum of costs legislated for interpretational services in civil cases.

According to Section 19(2), the court must understand the language used without the assistance of an interpreter. This is reinforced through Sections 20(1) and (2), providing that, in having a language of choice right, the court must understand the litigant without any form of interpretation. Section 19(2) precludes the possible complication where both languages are used in proceedings, obligating the court to understand both languages. Two languages may be used, for instance, where a witness to a case provides evidence in a language other than the language in which the proceedings are conducted. According to Section 21, interpretation is permitted where a witness or any party before court requests the services of an interpreter and such services must be made available on request. Sections 16 to 23 are inclusive and ensure all litigants and witnesses are treated equally and have equal access to courts, where language is not a barrier. Section 18, in fact, entrenches the guarantee that there be no disadvantage before the law.

The language of record is often a contentious point of discussion with reference to the judgment and precedent-setting judgments to be published in the law reports. Section 24(1) of the New Brunswick Official Languages Act (2002) deals with these issues where there is a bilingual language of record policy and is illustrative of linguistic inclusivity in 
New Brunswick. The objective of practical interpretation of the equality of two official languages is evident. Judgments must be made available in both languages where:

(a) it determines a question of law of interest or importance to the general public, or

(b) the proceedings leading to its issuance were conducted in whole or in part in both official languages.

The insertion of subsection (2) also addressed the potential time delays that may arise from the publication of a judgment in both official languages. The provision bears testament to the unwavering commitment of equality of status of both official languages. Of greater significance was the manner in which the legislature drafted the New Brunswick Official Languages Act (2002): instead of viewing time delays as a result of bilingual publication of judgments, the legislature skilfully drafted subsection (2) without limiting the right of litigants and other citizens in accessing judgments. This is the act of balancing rights without limiting either of the rights.

The legislative position in New Brunswick in the form of the New Brunswick Official Languages Act (2002) is said to be exemplary in nature in that New Brunswick is the only Canadian Province to be officially bilingual, both theoretically and practically, in all disciplines across society (Doucet, 2012: 59). Given the extensiveness of the New Brunswick Official Languages Act (2002), Doucet (2012) advances a theoretical discussion in an attempt to explain why a state would not just opt for the simplest solution of adopting the official language of the majority as the official language for use across all disciplines. In engaging with this paradox, it was stated that a state has two options in the process of language planning, namely the territorial or personal approach.

Doucet (2012:160) states that the adoption of a territorial-based approach will result in unilingualism in the specifically defined geographical area. Doucet (2012:160) advances further that this was a common human phenomenon where persons of the same linguistic community are positioned geographically. In the case of Canada, the personal approach may be ideal in the circumstances as there are only two official languages. Therefore, it is our opinion that the type of approach will be dependent on the nature of the linguistic framework of each country. Docuet (2012:161) also acknowledges the fact that a multilingual state faces greater concerns of linguistic choice in disciplines, such as the legislative process, national institutions, government services, administration of justice and education.

\section{Judicial interpretation and application of a bilingual language of record: case law}

Once again, the practicalities surrounding a bilingual language of record need to be assessed through relevant case law. The case law advanced in the proceeding paragraphs deals inter alia with the court's interpretation of litigants' language rights and the language of 
record. A further purpose of advancing Canadian case law is to illustrate the jurisprudential development in the courts' reasoning and interpretation of the provisions of the language rights. The cases are assessed with the aim of determining whether both the constitutional and legislative frameworks have been interpreted restrictively or purposively. Discussions below pertain to the selected cases in accordance with the doctrine of precedent.

Foucher (2012:333) explains that the Canadian courts ought to adopt a balance in interpreting the language provisions between an individual's human rights, the collective language rights and the constitutional framework giving effect to the national minority. Language rights are not to be interpreted narrowly, as opposed to other constitutionally enshrined rights. In avoiding narrow interpretation of language rights, the parameters and objectives of the language rights must be clarified by the courts (Foucher, 2012:234). The latter two points will be discussed in Chapter 7 with reference to the cases of AfriForum and Another v University of the Free State (2018); and Gelyke Kanse and Others v Chairman of the Senate of the Stellenbosch University and Others (2019), both South African CC judgments dealing with the parameters of language rights.

The interpretation of language rights was dealt with in the cases of Jones v A.G. of New Brunswick (1975) and Ford v Quebec (Attorney General) (1988). In both cases, the respective courts held that, although language rights were fully established rights, they were not absolute in nature and may therefore be limited where such limitations were reasonable in the circumstances (Foucher, 2012:234). The limitation of language rights in the South African context is discussed fully in Part One of Chapter 6. We engage with the limitations analysis of Section 36 of the Constitution, as well as the language-specific limitations analysis, namely the sliding scale formula (Currie \& De Waal, 2005:632) which takes into account the context in which the right is being limited.

The case of Reference re: Manitoba Language Rights (1985) was heard by the Supreme Court of Canada (SCC) following the enactment of the Charter of Rights and Freedoms (1982). The SCC in Manitoba (1985) contextualised the importance of language more broadly within society across disciplines. What is important for the purposes of the judgment was the court's statement that all rights contained in the Canadian Charter of Rights and Freedoms (1982), including language rights, be interpreted fully, where the SCC would follow a “... broad liberal and dynamic approach ..." (Doucet, 2012:162).

It was thought that the case of Reference re: Manitoba Language Rights (1985) would provide for further purposive interpretation of language rights; however, this was not to be, with the trilogy of cases that followed (Doucet, 2012:162). The trilogy comprised the following cases: Bilodeau v Manitoba (Attorney General) (1986); MacDonald v Montreal (City) (1986); and Societe des Acadiens du Nouveau Brunswick v Association of Parents for Fairness in Education (1986). 
In the case of MacDonald v Montreal (City) (1986), the facts briefly before the SCC on appeal from the Court of Appeal for Quebec were that the Appellant was initially charged and convicted in the court a quo of contravening a municipal by-law. The summons served on the English Appellant was in French only (1986:460). The Appellant alleged, in both the court a quo and before the Court of Appeal for Quebec, that the French-only summons violated his fundamental right espoused in Section 133 of the Constitution Act of 1867. In both instances, the Appellant was unsuccessful. The SCC held from the onset that the Appellant had no right to be summonsed in his own language as the provisions provide that the summons can be in either of the official languages; and, as such, there is no "obligation nor a duty" to use the other official language (1986:462). Reasoning further, the SCC (1986:462) stated that Section 133 of the Constitution Act of 1867, which established a language right, protected “... litigants, counsel, witnesses, judges and other judicial officers..." This right was not extended to the writers or issuers of pleadings nor those who were the recipients of summonses (1986:462).

In the same restrictive breath, the SCC (1986:462) noted that, although it may be “... desirable or fair for summonses to be bilingual to ensure comprehension by the recipient..., there was specific reference to this in the provisions of Section 133 of the Constitution Act of 1867. The SCC (1986:462), in validating the narrow approach, held that it was not the court's responsibility “... under the guise of interpretation, to improve upon, supplement or amend this historical constitutional promise". The SCC (1986:463) held further that, in fact, language rights during judicial proceedings were not rights per se, but rather a consequential part of the right to a fair trial. In this instance, the court would be under an obligation to ensure that proceedings are understood by the accused with the aid of translation services (1986:463). The appeal was subsequently dismissed.

The MacDonald v Montreal (City) (1986) case highlighted that, although the Canadian Charter of Rights and Freedoms was progressive, this remained in theory and not in practice; and where the court was required to apply the provisions in a positive, practical manner, they opted instead for a limiting, restrictive interpretive approach. Similar to the majority judgment in the case of AfriForum and Another v University of the Free State (2018), the court's reasoning brought into question the role of the judiciary in safeguarding the constitutional and legislative ideals in the best interests of the citizens.

The dissenting judgment of Wilson J in MacDonald v Montreal (City) (1986) was in stark contrast to the majority judgment. Wilson J held that the litigant, namely the Appellant in the matter at hand, had a right to use his own language, as espoused in Section 133 of the Constitution Act of 1867. Wilson J (1986:463) recognised that a language right was in existence, and further explained the parameters of the right by interpreting that a correlative duty is imposed on the state during judicial proceedings to accommodate the right. In terms 
of what was meant by "accommodate", Wilson J (MacDonald v Montreal (City) 1986:463) explained that the use of the words "may" and "either" in the provisions of Section 133 of the Constitution Act of 1867 were not inserted with the purpose of conferring a discretionary choice on the state to choose the official language of their choice to communicate with the litigant, but instead to confer such an option on the litigant.

As a minimum requirement of Section 133 of the Constitution Act of 1867, all documents emanating from and initiating court processes should be in an official language which the recipient thereof understands. If the recipient's language of choice is not known, the state is obliged to advise that a translation of the documents in the official language of his choice is available upon application (Wilson J, MacDonald v Montreal (City) 1986:464). This reasoning, according to Wilson J (1986:463), gives practical meaning to the constitutional and legislative provisions that the official languages are equal in status and should be treated as such in judicial proceedings.

The dissenting judgment in MacDonald v Montreal (City) (1986) provides for the parameters of the right to be interpreted in favour of the litigant upon whom the right is conferred. The interpretation by Wilson J in MacDonald (1986) is important for the discussion pertaining to South Africa in the forthcoming chapters, specifically with regard to the interpretation of the constitutional provisions and the incessant inclusion of words such as "may" and "either". It is also important in drawing parallels with the dissenting judgment of Froneman J in the case of AfriForum and Another v University of the Free State (2018).

In the case of Bilodeau v Manitoba (Attorney General) (1986), the appeal concerned the conviction of an English accused for the contravention of a Highway Traffic Act. The summons was issued in French only. The Appellant alleged that the French summons was a violation of Section 23 of the Manitoba Act of 1870 (1986:449). Section 23 of the Manitoba Act (1870) prescribes that the printing of all legislation must be done in both English and French. To this effect, the majority judgment held that it was not mandatory, but rather directory in nature (1986:452-454). In substantiating this viewpoint, the majority adopted the precise reasoning of the majority in the MacDonald v Montreal (City) case (1986). In doing so, the court explained that, in this instance, the legislation was only in French as the prescribed period for translation into both English and French had not yet elapsed, hence the fact that the legislation from which the summons was issued was valid and did not contravene Section 23 of the Manitoba Act (1870). The appeal was subsequently dismissed.

Wilson J in Bilodeau v Manitoba (Attorney General) (1986) wrote a minority judgment. Wilson J (1986:458) therefore concurred with the majority in dismissing the appeal. However, his reasons for the dismissal differed significantly. Wilson J (1986:458) held that Section 23 of the Manitoba Act (1870) was mandatory and not directory. As such, the 
Appellant's language rights entrenched under Section 23 of the Manitoba Act (1870) were in fact contravened. The only reason why Wilson J dismissed the appeal was that, if not, it would have opened the floodgates to litigation.

The third case in the trilogy, namely Societe des Acadiens du Nouveau v Association of Parents for Fairness in Education (1986), concerned an appeal from the Court of Appeal for New Brunswick regarding the Official Languages Act of New Brunswick (2002). The primary issue on appeal was the interpretation of the parameters of Section 13(1) of the Official Languages of New Brunswick Act (2002) which states that a party to court has the right to be heard in a language of their choice by the members of the court in both the oral proceedings and written pleadings.

Engaging with the provision above, the court explained that it was best to trace the sources of legislation which gave effect to the enactment of the New Brunswick Official Languages Act (2002), namely Section 19 of the Canadian Charter of Rights and Freedoms (1982), as well as Section 133 of the Constitution Act (1867). The court held that both Section 133 of the Constitution Act (1867) and Section 19 of the Canadian Charter of Rights and Freedoms (1988) did not guarantee that a litigant had a right to be heard in a language of choice or to be understood in that language of choice (Societe des Acadiens du Nouveau v Association of Parents for Fairness in Education, 1986:552). The court held further that it must be noted that language rights are separate to the requirements of natural justice (Societe des Acadiens du Nouveau v Association of Parents for Fairness in Education, 1986:552). Simply put, the court did not see language rights as a possible catalyst determining or influencing whether or not substantive justice or any form of justice is achieved. The court held that courts should "... pause before they decide to act as instruments of change, with respect to language rights" (Societe des Acadiens du Nouveau $v$ Association of Parents for Fairness in Education, 1986:552). Moreover, the courts were cautioned to "... approach them with more restraint than they would in construing legal rights" (Societe des Acadiens du Nouveau $v$ Association of Parents for Fairness in Education, 1986:552). The court ordered that the appeal be dismissed.

The trilogy of cases illustrated the adoption of a restrictive interpretative approach of the various language rights, as evidenced above. The court in $R$ v Beaulac (1999) rejected the restrictive approach adopted in the Societe case (1986), reasoning that, regardless of the facts before a court, where language rights are concerned, such language provisions must be interpreted purposively.

Purposive interpretation must be guided by the need to ensure the "preservation" and "development" of official language communities in Canada (1999:770). The court held that, in criminal cases, courts were obligated to ensure that they were bilingually functional. This would allow for equal use of both official languages of Canada, in accordance with the 
core principle of linguistic duality. This, the court said, reaffirmed the language right as a substantive right and not a procedural right (1999:770). The court dismissed the reasoning that language rights were part of the right to a fair trial. Instead, the court held that the right of the accused to be heard in a language of their choice was in place to ensure the accused gained equal access to a public service, one that was linguistically competent to respond fully to the right (1999:772).

The purposive approach adopted in $R \mathrm{v}$ Beaulac (1999) was adopted in the case of $R \mathrm{v}$ Pooran (2011) - a case on appeal. Briefly, the facts dealt with the interpretation of Section 4(1) of the Alberta Languages Act of 2000 which states:

Any person may use English or French in oral communication in proceedings before the following courts.

The Appellant argued that Section 4(1) inferred that English and French were the official languages of the Provincial Court proceedings, thus a French-speaking accused was entitled to a French-speaking prosecutor ( $R$ v Pooran, 2011:78). In a civil trial, the Frenchspeaking litigant has a right to be understood in French, without interpretation services being employed. In both instances, a judicial officer must be linguistically equipped in the language of choice ( $R \mathrm{v}$ Beaulac, 1999:78).

The Crown, acting as the Respondent in $R$ v Pooran (2011), argued that Section 4(1) entitled the accused to have proceedings interpreted in French but not to have the entire trial conducted in French (2011:78). Brown J, in delivering judgment in $R$ v Pooran (2011), imparted the reasoning in the $R \mathrm{v}$ Beaulac case (1999). Brown J (2011) accordingly held that the appeal succeeds, as Section 4(1) did entitle the accused to a French trial without the employ of interpretation. In Brown J's judgment, it was clearly stated that liberal and purposive interpretation was required in all instances concerning language rights $(R \mathrm{v}$ Pooran, 2011:79).

The Canadian case law provides an overview of the development the court has undergone in purposively interpreting language rights and the parameters thereof. The case law also illustrates how the courts have implemented the provisions that both English and French are languages of record and that the accused in criminal cases has the right to have the trial conducted in either of these languages based on his choice. Regardless of which language is chosen the court must be linguistically competent in both official languages.

The discussion on Canada has provided an overview of the Canadian constitutional and legislative language developments which have culminated in the entrenchment of language rights in recognising the official bilingualism of the country. The Canadian model illustrates that language has a significant role to play in the legal system for both litigants and legal professionals. This is evidenced in the New Brunswick Official Languages Act (2002). 
More pertinently, the model is illustrative of the ability that more than one language can be employed successfully in judicial processes at all levels without the aid of translation and interpretation services and without causing unnecessary delay in the delivering of judgments and the consequent administration of justice.

As with the legislative developments, the courts, specifically the SCC, appeared hesitant (if not steadfast) in not giving effect to language rights, both in the employ of court proceedings and in the broader legal system. There was a definite divorce between language and law which the judiciary created, both directly and indirectly, through the trilogy of cases. The mere fact that the judiciary turned their backs on the restrictive approach to language rights and the limited role of language it recognised in the legal system, illustrates that, for litigants, legal professionals and the Canadian society, it is important that language assumes a rightful place in the legal system. Moreover, the case law following the trilogy of cases upheld the constitutional and legislative frameworks and the ideals of official bilingualism. The case law further provided an example of how skilful purposive interpretation should be undertaken where language rights were said to be substantive and not procedural in nature. The Canadian model is proof that, regardless of the restrictive constitutional and legislative frameworks, as well as the narrow approach of the judiciary in the trilogy of cases and prior to that, a determined resolve for linguistic equality can be achieved in a legal system where the important role of language is recognised.

\section{India's sociolinguistic landscape}

The Indian sociolinguistic landscape is characterised by the political influences that ultimately determined the language question. Crystal (2003) highlights the political events that led to the growth and dominance of English in India. The first English influences lie with the establishment of the British East India Company in 1600 (Crystal, 2003:47). In 1612, the British East India Company began its first trading station in Surat and later in Madras, Bombay and Calcutta. These cities are important to note for the forthcoming discussions concerning the dominance of English and the subsequent language divide across the north and south of India. British power was consolidated from 1784 to 1858 when the India Act of 1858 established a Board of Control that required direct reporting to the British Parliament (Crystal, 2003:47). The use of English was strengthened during the period of British sovereignty (1765-1947) during which time English was the medium of administration and education throughout the subcontinent (Crystal, 2003:47). The language question gained momentum in the early nineteenth century with the debating of an educational policy of learning and teaching English (Crystal, 2003:47). The establishment of the Universities of Bombay, Calcutta and Madras in 1857 saw English become the primary medium of instruction, cementing its development (Crystal, 2003:48). Again, this point is important for the forthcoming discussions where legal education is discussed in relation to the use 
of language in the courts. In the 1960s, a language war broke out in India between the supporters of English, Hindi and other regionally spoken languages in the south of India. This resulted in the 'three language formula' where English was introduced as the primary alternative to the local state language (Crystal, 2003:48).

Parallels can be drawn with South Africa where the historical influence of colonialism and the growth of a language, in this instance English, was due to political and economic interests; and how, as a result thereof, the colonial language was seen as a language of unification. This speaks to the global dominance of English and how, through political and economic means, English as a language has been able to grow in both use and popularity in countries where the status and use of indigenous languages have been undermined. Furthermore, this point relates to the relationship between language and power, as explicated in this chapter with reference to Australia. Linguistic transformation lies in the hands of those who are powerful; and if the majority do challenge the English status quo, it results in intra-language battles or the adoption of English to fight for the African languages, as seen in South Africa.

Regarding majority, it is interesting to note that with the Indian population exceeding one billion, the number of English speakers rises as well, contributing to the growth of English as a second language, rather than the use and development of indigenous languages. What follows is a presentation of the language demographics in India emanating from the Census.

\section{Indian language demographics}

In 2011, India released its Census results. As will be evident from Part Two of Chapter 6, the language Census (2011) of India differs from that of South Africa, given that the Indian Constitution recognises 22 official languages. The Indian Census (2011:8) records 121 languages are spoken in India. The Census (2011) provides this table which records the language demographics pertaining to the 22 official languages.

Table 3.1 illustrates that Hindi is the most commonly spoken language in India. The Indian Census (2011:10) recorded 259,678 people who reported that English was their mother tongue. If one were to place English alongside the scheduled languages in Table 3.1, it would be sequenced after Punjabi language. This would amount to approximately $2 \%$ of the population; yet it is such a dominant language across society and in high status domains such as the legal system and higher education. 
TABLE 3.1 Constitutionally scheduled languages arranged in descending order of use

\begin{tabular}{|l|c|c|}
\hline Language & $\begin{array}{c}\text { Persons who returned } \\
\text { the language as their } \\
\text { mother tongue }\end{array}$ & $\begin{array}{c}\text { Percentage to total } \\
\text { population }\end{array}$ \\
\hline Hindi & $52,83,47,193$ & 43.63 \\
\hline Bengali & $9,72,37,669$ & 8.03 \\
\hline Marathi & $8,30,26,680$ & 6.86 \\
\hline Telugu & $8,11,27,740$ & 6.70 \\
\hline Tamil & $6,90,26,881$ & 5.70 \\
\hline Gujarati & $5,54,92,554$ & 4.58 \\
\hline Urdu & $5,07,72,631$ & 4.19 \\
\hline Kannada & $4,37,06,512$ & 3.61 \\
\hline Odia & $3,75,21,324$ & 3.10 \\
\hline Malayalam & $3,48,38,819$ & 2.88 \\
\hline Punjabi & $3,31,24,726$ & 2.74 \\
\hline Assamese & $1,53,11,351$ & 1.26 \\
\hline Maithili & $1,35,83,464$ & 1.12 \\
\hline Santali & $73,68,192$ & 0.61 \\
\hline Kashmiri & $67,97,587$ & 0.56 \\
\hline Nepali & $29,26,168$ & 0.24 \\
\hline Sindhi & $27,72,264$ & 0.23 \\
\hline Dogri & $25,96,767$ & 0.12 \\
\hline Konkani & $22,56,502$ & Negligible \\
\hline Manipuri & $17,61,079$ & \\
\hline Bodo & $14,82,929$ & 0.19 \\
\hline Sanskrit & 24,821 & 0.512 \\
\hline
\end{tabular}

\section{Indian constitutional framework}

The discussions above have referred to the Constitution of India, with specific reference to the fact that official status is conferred on 22 languages, as listed in Table 3.1. The following extracted provisions are relevant to our discussions:

Cultural and Educational Rights

29. (1) Any section of the citizens residing in the territory of India or any part thereof having a distinct language, script or culture of its own shall have the right to conserve the same. 
(2) No citizen shall be denied admission into any educational institution maintained by the State or receiving aid out of State funds on grounds only of religion, race, caste, language or any of them.

30. (1) All minorities, whether based on religion or language, shall have the right to establish and administer educational institutions of their choice.

(2) The State shall not, in granting aid to educational institutions, discriminate against any educational institution on the ground that it is under the management of a minority, whether based on religion or language.

Chapter I - Language of the Union

343. (1) The official language of the Union shall be Hindi in Devanagari script.

The form of numerals to be used for the official purposes of the Union shall be the international form of Indian numerals.

(2) Notwithstanding anything in clause (1), for a period of fifteen years from the commencement of this Constitution, the English language shall continue to be used for all the official purposes of the Union for which it was being used immediately before such commencement:

Provided that the President may, during the said period, by order authorise the use of the Hindi language in addition to the English language and of the Devanagari form of numerals in addition to the international form of Indian numerals for any of the official purposes of the Union.

(3) Notwithstanding anything in this article, Parliament may by law provide for the use, after the said period of fifteen years, of -

(a) the English language, or

(b) the Devanagari form of numerals, for such purposes as may be specified in the law.

344. (1) The President shall, at the expiration of five years from the commencement of this Constitution and thereafter at the expiration of ten years from such commencement, by order constitute a Commission which shall consist of a Chairman and such other members representing the different languages specified in the Eighth Schedule as the President may appoint, and the order shall define the procedure to be followed by the Commission.

(2) It shall be the duty of the Commission to make recommendations to the President as to -

(a) the progressive use of the Hindi language for the official purposes of the Union;

(b) restrictions on the use of the English language for all or any of the official purposes of the Union;

(c) the language to be used for all or any of the purposes mentioned in article 348;

(d) the form of numerals to be used for any one or more specified purposes of the Union;

(e) any other matter referred to the Commission by the President as regards the official language of the Union and the language for communication between the Union and a State or between one State and another and their use.

(3) In making their recommendations under clause (2), the Commission shall have due regard to the industrial, cultural and scientific advancement of India, and the just claims and the interests of persons belonging to the non-Hindi speaking areas in regard to the public services. 
(4) There shall be constituted a Committee consisting of thirty members, of whom twenty shall be members of the House of the People and ten shall be members of the Council of States to be elected respectively by the members of the House of the People and the members of the Council of States in accordance with the system of proportional representation by means of the single transferable vote.

(5) It shall be the duty of the Committee to examine the recommendations of the Commission constituted under clause (1) and to report to the President their opinion thereon.

(6) Notwithstanding anything in article 343, the President may, after consideration of the report referred to in clause (5), issue directions in accordance with the whole or any part of that report.

Chapter II - Regional Languages

345. Subject to the provisions of articles 346 and 347, the Legislature of a State may by law adopt any one or more of the languages in use in the State or Hindi as the language or languages to be used for all or any of the official purposes of that State: Provided that, until the Legislature of the State otherwise provides by law, the English language shall continue to be used for those official purposes within the State for which it was being used immediately before the commencement of this Constitution.

346. The language for the time being authorised for use in the Union for official purposes shall be the official language for communication between one State and another State and between a State and the Union: Provided that if two or more States agree that the Hindi language should be the official language for communication between such States, that language may be used for such communication.

347. On a demand being made in that behalf the President may, if he is satisfied that a substantial proportion of the population of a State desire the use of any language spoken by them to be recognised by that State, direct that such language shall also be officially recognised throughout that State or any part thereof for such purpose as he may specify.

Chapter III - Language of the Supreme Court, High Courts, etc.

348. (1) Notwithstanding anything in the foregoing provisions of this Part, until Parliament by law otherwise provides -

(a) all proceedings in the Supreme Court and in every High Court,

(b) the authoritative texts -

(i) of all Bills to be introduced or amendments thereto to be moved in either House of Parliament or in the House or either House of the Legislature of a State,

(ii) of all Acts passed by Parliament or the Legislature of a State and of all Ordinances promulgated by the President or the Governor of a State, and

(iii) of all orders, rules, regulations and bye-laws issued under this Constitution or under any law made by Parliament or the Legislature of a State, shall be in the English language.

(2) Notwithstanding anything in sub-clause (a) of clause (1), the Governor of a State may, with the previous consent of the President, authorise the use of the Hindi language, or any other language used for any official purposes of the State, in proceedings in in the High Court having its principal seat in that State: Provided that nothing in this clause shall apply to any judgment, decree or order passed or made by such High Court. 
(3) Notwithstanding anything in sub-clause (b) of clause (1), where the Legislature of a State has prescribed any language other than the English language for use in Bills introduced in, or Acts passed by, the Legislature of the State or in Ordinances promulgated by the Governor of the State or in any order, rule, regulation or byelaw referred to in paragraph (iii) of that sub-clause, a translation of the same in the English language published under the authority of the Governor of the State in the Official Gazette of that State shall be deemed to be the authoritative text thereof in the English language under this article.

349. During the period of fifteen years from the commencement of this Constitution, no Bill or amendment making provision for the language to be used for any of the purposes mentioned in clause (1) of article 348 shall be introduced or moved in either House of Parliament without the previous sanction of the President, and the President shall not give his sanction to the introduction of any such Bill or the moving of any such amendment except after he has taken into consideration the recommendations of the Commission constituted under clause (1) of article 344 and the report of the Committee constituted under clause (4) of that article.

These constitutional provisions quoted in full above are extensive in their mandate. However, a point of critique is that the majority of these provisions are qualified, or have internal qualifications built into them that secure the use of English. To an extent, the provisions are extensive and do reflect progress in that they include Hindi, specifically in high status domains. Simply put, though, whether one views these provisions from a positive or negative perspective depends on the type of interpretation employed, i.e., restrictive interpretation or purposive interpretation.

There are important points to note emanating from these provisions, the first of which is found in Article 29(2) above, providing that an individual may not be turned away from an educational institution based on, amongst other factors, language. This can be crossreferenced to the discussion on Indian legal education and how universities in India are battling to grapple with the language question that is resulting in a language divide that is also geographical, i.e., between the north and south. This also relates to the point of language and power in India. One must be conscious of the underlying discrimination and the classist society in India which is based on the caste system in which language is inherent. This, despite the fact that the Indian constitutional provisions exclude discrimination based on language and caste.

Article 29(2) of the Constitution of India is similar to the language in educational rights in Section 29(2) of the South African Constitution, advanced in Part One of Chapter 6. We mentioned that the provisions quoted earlier place Hindi alongside English, as per Article 343. The dominance of English in India can be seen from the provisions that attempt to place Hindi on an equal footing. Article 343 resembles the provisions of Section 6 of the South African Constitution that elevates the status and use of the nine African languages that were previously marginalised. In supporting Article 343, the Constitution 
of India provided for a Commission to be established 15 years following the enactment of the Constitution. Based on the provisions of the Indian Constitution, it appears that the Commission's purpose was similar to that of the Language Task Plan Group (LANGTAG) (1996) concerning South Africa. This will be discussed in forthcoming paragraphs. Furthermore, the provisions of Article 343 somewhat overlap with the mandate of PanSALB in South Africa, as per Section 6(5) of the South African Constitution.

Cognisant of Article 345, there is a divide between language use for the union (country) and state (regional and provincial) purposes. This distinction is important where, in the states, a regional language can be used for official purposes, such as in the courts. We discuss the point more fully in the paragraphs below.

What is of most significance about the provisions quoted above, for the purposes of this research, is the inclusion of Article 348 regulating the use of language in the SC and all High Courts. There is no such provision in the South African Constitution nor in the Superior Courts Act 10 of 2013. Article 348, however, falls short of being progressive, in our opinion, as it prescribes that English be used and ultimately be the language of record. This provision does not correlate with the language demographics provided in the Indian Census (2011) represented in Table 3.1, given that English is spoken by a mere 2\% of the population. Furthermore, Article 348 provides that all legislation and all laws be enacted in English. A parallel can be drawn between the case of Lourens v State Party: Republic of South Africa (2018) and also with the discussion below: that having legislation and other primary texts in English only means that the large majority cannot access the law, neither can universities teach law students in a language other than English, resulting in an English-only language of record policy. There is a thin, positive aspect provided in subsection (3) that permits the use of Hindi in these courts, but this is discretional. The relationship between language and power and language and politics comes to the fore with this discretion, where the litigants do not have this power that directly affects their level of access to justice and procedural fairness.

\section{Language of record and proceedings in Indian courtrooms}

The constitutional provisions above are clear on the language of record in the SC and all High Courts, but not for the lower courts; this is where the majority of literature and contention has been based. As with any debate concerning the use of language in a legal system, there will be opposing views. India is no different. The language question in courts and the country more broadly is continuously debated, with no end in sight. One of the primary reasons cited for the ongoing debate is the linguistic diversity of India which, in most instances, is not viewed as a rich resource but rather as a dividing problem. Before engaging in a thematic account of the developments and debates concerning the language of record and proceedings in Indian courts, the language of record in the SC must be dealt with. 
Although constitutionally determined, the language of record in the SC of India has been criticised as eluding the majority of the people who cannot speak, read, write or understand English. According to the SC Registry, an increase in the number of litigants requesting the translation of judgments into the indigenous languages has been recorded (Nambiar, 2019). In responding to the numerous requests, the SC Registry reported that it would make its judgments available in regional languages on the court website (Nambiar, 2019). The judgments would be translated into Assamese, Hindi, Kannada, Marathi, Odia and Telegu (Nambiar, 2019). This development followed a previous rejection by the judiciary to make Hindi the official language of all courts in India (Sonewal, 2016). The rejected proposal concerning the SC and the 24 High Courts was based on the fact that Hindi was not the accepted language of communication in many parts of India (Sonewal, 2016). Another reason cited for the dismissal is that cases tend to have a delay of five months for translation purposes. In 2008, the Law Commission, in its $216^{\text {th }}$ report, held that introducing Hindi as a compulsory language of record in the SC and all High Courts was not feasible and that the Constitution of India was clear on the matter of the language of record (Sonewal, 2016).

The situation in the lower courts in the states differs given the absence of constitutional and legislative directives on the language of record. As a result of this situation, lower courts use the regional (local) languages for court proceedings, thus the languages of record (Sonewal, 2016). This permits litigants the opportunity of understanding proceedings and filing documents in their mother tongue, so justice is seen to be done and access to justice is enhanced for ordinary citizens and not just a political English-speaking elite (Naidu, 2018).

Speaking on this topic of access to justice for all Indian citizens, Vice President Shri M Venkaiah Naidu (2018) stated that the language used in courts should be understood by the petitioners who are seeking justice. Naidu (2018) explained that, from a political perspective, he was of the view that language use in courts was grounded in the Constitution where the judiciary is a key pillar of the democratic polity. Naidu (2018) further explained the importance of the judiciary in upholding the principles of the Constitution and stated that to exclude litigants on grounds of language would be abandoning this duty. A parallel can be sought with the judgment by Froneman $\mathrm{J}$ in the case of AfriForum and Another v University of the Free State (2018) discussed in Chapter 7. Simply put, it can be questioned whether a monolingual language of record policy does not undermine the constitutional provisions and discriminate against the majority of the people on grounds of language.

The situation is complicated by the fact that the Constitution of India recognises 22 languages besides English. There are, however, regional languages that can be used in the lower courts and this can be regulated by a policy in which the regional language(s) are placed alongside English as is done in Canada and, to an extent, in Belgium as per the discussions earlier in this chapter. This would require the collective effort of the judiciary 
(including legal practitioners) and the state. As with any society, this support is subjective and speaks to the power relations and agendas pursued by these individuals who are tasked with affecting the rights of the majority.

Sonewal (2016), through an investigation of whether it would be feasible for Hindi to be used in all courts of India, recorded the views of legal practitioners. Vivek Sood, a Senior Advocate in the Delhi High Court, provided three reasons why English should be the sole official language of record for all courts. Firstly, English was an established legal language, having been used in Indian courts for a period exceeding one 150 years (Sonewal, 2016). Secondly, the introduction of Hindi into the courts will be a burden on the courts (Sonewal, 2016). The second point was substantiated through the third, with Sood explaining that there was already a huge backlog in cases, coupled with a shortage of judges, amongst other issues that needed to be addressed as a matter of urgency, rather than being fixated on the fact that English, a colonial language, was being used (Sonewal, 2016). Sood's views undermine the important function of language and the role it plays in facilitating access to justice in a multilingual country where the majority do not understand English. Furthermore, his position seems to reflect that the English-only agenda does not adversely affect him, so why change it? The importance of the language question is downplayed by what is perceived as more pressing.

Yatindra Chaudhary, an advocate in the SC, presents both sides of the coin, arguing that the introduction of Hindi will be of benefit to the litigants; that, in some instances, cases may proceed in a language other than English where the judicial officer is competent and comfortable to proceed in that language (Sonewal, 2016). Allahabad High Court permits the use of Hindi for court proceedings (Sonewal, 2016). Chaudhary believes the introduction of Hindi will assist lawyers who have a limited command of the English language (Sonewal, 2016). Chaudhary recognises the limitations, not of introducing indigenous languages, but rather Hindi only, as there is a language divide in India between the north and south and east and west (Sonewal, 2016). Simply put, not a one-size-fits-all policy but regionallybased language policies will be more effective.

Another advocate of the SC, Aishwarya Bhati, expressed similar views, providing more examples of courts which permitted the use of languages other than English, namely: Rajasthan courts use Hindi, while the courts in Gujarat permit the use of Gujarati language (Sonewal, 2016). There is consensus by some advocates for the use of languages other than English but also the acknowledgement of the difficulties in doing this, given the language diversity, the development of English as a legal language and its colonial history which ensured the dominance of English. 
The discussion on the language of record in Indian courts points to the need to have the entire system transformed and in which attorneys and advocates enter the legal profession having sound linguistic competency in a regional language in which they practise, as is the case in Belgium and Canada.

The next section of this chapter advances a discussion on the legal education in India, with specific reference to the language question.

\section{Indian legal education through the medium of English}

Access to education in English from primary school is not standard, although this is on the rise given the status of English as a global language. Hindi is the majority spoken language in the north of India where a large number of law schools and universities are located (Getman, 1969:517). In the preceding paragraphs, we mentioned the language war in India and the underlying caste system. This dates back to the 1960s in the education system where there was an insurgence in the north to do away with English in favour of Hindi in all schools and courts (Getman, 1969:517). Violent protests broke out at universities and law colleges with Banaras Hindu University going to the extent of removing all traces of English, including signage. At Banaras Hindu University, as well as all other law colleges and universities in the north of India, with the exception of students in Delhi, students had a minimal understanding of English (Getman, 1969:517). Their limited English linguistic competency made it difficult to engage with the cases and other academic and legal texts written in English (Getman, 1969:517). As a result, the north was primarily educated in Hindi and the south educated in English. This sparked a further divide between students who could not be recruited to universities in the north, given the growing tensions (Getman, 1969:518).

There is a need to educate students in their mother tongue and this should not result in the exclusion of other students from at universities or law colleges. Getman (1969:519) notes that course material and legal and academic texts will have to be translated in order to graduate lawyers who have a sound accord of the language(s) and where these students themselves are not disadvantaged as the litigants are. Getman (1969:519) recommends that courses be taught bilingually to ensure representation across Indian states and to allow students to be in a position to express themselves in their mother tongue, while also acquiring the skill in English. 


\section{Conclusion}

This chapter is similar to Chapter 2 in that there are common threads among the international case studies. The case studies of Belgium and Canada illustrate the inclusivity that is being achieved in their legal systems through the prioritisation of the language question. In both countries, language is seen as a resource in courts. This progressiveness is enabled and regulated through constitutional and legislative frameworks. Indeed, there is a history of language marginalisation or restrictive interpretation; both case studies have proven that this can be overcome where commitment is key among all relevant persons and sectors in society. Languages are viewed as equal in status and use and the speakers of these languages are treated equally. The regionally based language policies are effective and the language policies for the legal system are workable and give effective meaning to language rights. The language attitudes and practices in both these countries can be emulated by South Africa and other African countries.

Australia and India are similar to South Africa with regard to historical political influences, particularly in the form of English that was entrenched as a result of colonialism. The countries are also similar in that there is greater language diversity than the other international models. It can be argued from the discussions that language diversity can be a complication depending on which view is adopted. In these countries, the language question was problematised; language, power, politics and economics are closely related in advancing a specific agenda of a political, English-speaking elite. There is an inherent system of inferiority bestowed on Aboriginal people and their languages. This is evidenced from the establishment of Bush courts and the non-existence (or, in some areas, low levels) of interpretation services for Aboriginal litigants. The disregard by a political Englishspeaking elite in Australia is evidenced by the sentiments of the Chief Minister as captured by MacFarlane et al. (2019) who said that providing interpretation services equated to providing a wheelchair to able people.

South Africa must take note of the danger of having a monolingual language of record policy in a multilingual country and the effect this will have on the indigenous people and their languages. Furthermore, that when adopting a monolingual language of record policy, interpretation services need to be of the highest level and readily available at all times, at the state's expense.

The case study of India also presents as a complex model in which language in a multilingual country is further problematised by cultural differences inherent in the caste system. India, although making an effort in certain aspects of the legal system, is plagued by additional problems such as the attitude of legal practitioners towards the indigenous languages and divisive higher education language policies. This is particularly important for South Africa, 
given the recent judgments in the cases of Gelyke Kanse and Others v Chairman of the Senate of the Stellenbosch University and Others (2019) where universities are adopting English-only language policies on the basis of access and transformation.

As with Chapter 2, the international case studies have highlighted the global dominance of English which, although spoken by a minority, is advanced through power, politics and economics. When English is the sole official language of record and is used in proceedings to the exclusion of the indigenous languages, a country will not be inclusive and will be divided along lines of language. This must be avoided. Where language policies are drafted that counteract this form of discrimination and marginalisation, inclusivity is achieved, as in Belgium and Canada.

The preceding two chapters have shown that language usage and policies for courts remains a politically and economically motivated process. The African case studies in Chapter 2 have illustrated that language usage, in particular that of the indigenous languages, is underresourced and these languages are not seen as worthy of use in high status domains. English remains the default option on the African continent. The international case studies of India and Australia prove likewise that English is used regardless of the fact that the indigenous people are marginalised and in fact discriminated against on grounds of language. Belgium and Canada do however prove that languages other than English can be used for a more inclusive legal system, one that enables access to justice through a litigant's mother tongue. The geographical language planning approach adopted in Belgium and New Brunswick in Canada have proven to be both practical and inclusive. Nevertheless, in the chapter that follows, we begin to unpack the complexities of using the indigenous languages in South African courts and the resultant hegemonic power of the English-speaking elite in pursuing a monolingual language of record policy. 